\title{
Ceratocystis Wilt of Cacao-A Disease of Increasing Importance
}

\author{
Christine J. Engelbrecht, Thomas C. Harrington, and Acelino Alfenas
}

First and second authors: Department of Plant Pathology, Iowa State University, Ames 50011; and third author: Dept. de Fitopatologia, Universidade Federal de Viçosa, Viçosa MG Brazil.

\begin{abstract}
Engelbrecht, C. J., Harrington, T. C., and Alfenas, A. 2007. Ceratocystis wilt of cacao-A disease of increasing importance. Phytopathology 97: 1648-1649.

Ceratocystis cacaofunesta (formerly $C$. fimbriata) causes a lethal wilt disease of cacao (Theobroma cacao) in the Caribbean and Central and South America. Recent studies employing phylogenetics, intersterility, and host range separate the cacao pathogen from other strains of the $C$.

fimbriata complex. Ceratocystis wilt has been managed through genetic resistance, but the disease is an emerging problem in Bahia, Brazil, where it was recently introduced. Genetic studies indicate that populations of the fungus in Costa Rica, Colombia, and Bahia may have been introduced on cacao cuttings; whereas populations in Rondônia, Brazil, and western Ecuador appear to be native. The fungal genotype present in Bahia is similar to those found in Rondônia and may have been introduced on propagative material with witches' broom resistance.
\end{abstract}

Ceratocystis wilt of cacao causes wilting and death of cacao (Theobroma cacao L.) and the related genus Herrania. It is caused by the host-specialized fungus Ceratocystis cacaofunesta Engelbrecht \& Harrington, which was recently described as a species distinct from $C$. fimbriata (10). C. cacaofunesta has been identified only in the Caribbean, Central and South America; thus, it may be indigenous to the Americas $(1,10,13)$.

C. cacaofunesta typically enters cacao plants through fresh wounds, such as those caused by pruning or pod harvesting (21), and it moves through the host in the secondary xylem. Machete blades are an efficient means by which the pathogen spreads (21), hence the common name of the disease, 'mal de machete'. Ambrosia beetles of the genus Xyleborus often attack affected trees (28), liberating frass as they excavate their galleries (16). The frass contains aleurioconidia (chlamydospores) and conidia of the pathogen and may be carried by wind or rain splash to wounds on other trees (15). Fungal-feeding nitidulid beetles are vectors of ascospores of other members of the C. fimbriata complex (8, $14,17,23$ ) but have not been associated with cacao wilt. Like other members of the $C$. fimbriata complex, $C$. cacaofunesta is homothallic through unidirectional mating type switching (36), and introduced populations can persist in an essentially clonal manner through asexual reproduction and production of sexual spores through selfing.

History and range of Ceratocystis wilt. Ceratocystis wilt of cacao was first reported in western Ecuador in 1918 (27). It resulted in extensive damage in Colombia after 1940, in Costa Rica in 1958 (although it may have been present as early as 1926) (27), and in Venezuela in 1958 (33). It caused severe disease in Trinidad in the late 1950s (31) and has also been reported in Guatemala (29) and Peru (30). The pathogen was found in the southwestern Amazon (Rondônia, Brazil) in 1978 (4) and, more recently, in Bahia, Brazil (6), which is out of the native range of T. cacao.

Corresponding author: C. J. Engelbrecht; E-mail address: cengel@iastate.edu

doi:10.1094/PHYTO-97-12-1648

(C) 2007 The American Phytopathological Society
The genus Theobroma is indigenous from southern Mexico to the Amazon Basin (25), with many species on each side of the Andes (2). It is thought that the rising of the Andes may have facilitated speciation within the genus by separating previously widely distributed Theobroma populations (9). T. cacao is probably indigenous to the Upper Amazon region (7) but was domesticated in pre-Columbian times in Central America (5). An alternative hypothesis is that cacao is indigenous to the region from southern Mexico to Guyana-Amazon (9), but most genetic studies point to the Upper Amazon as the center of diversity of this species $(11,12,18-20,24,26,34,35)$. Host-specialized pathogens sometimes evolve in the same area as the plants they affect, and it is possible that $C$. cacaofunesta evolved on cacao in the Upper Amazon or on another Theobroma species west of the Andes.

Two other serious diseases of cacao, witches' broom (Moniliophthora (syn. Crinipellis) perniciosa) and frosty pod rot (Moniliophthora roreri), also were first recognized in northern South America and then spread to other cacao-growing regions (33). C. cacaofunesta may be another example of a cacao pathogen that has spread from this region throughout Central and South America.

Ceratocystis cacaofunesta as a newly described species. C. cacaofunesta is a member of the Latin American clade of the C. fimbriata species complex, which shows substantial genetic variation and a wide range of hosts $(1,3,10,13,17,22,32)$. C. cacaofunesta was recently described as distinct from $C$. fimbriata based on minor morphological differences, pathogenicity to cacao, internal transcribed spacer (ITS)-rDNA sequences, and intersterility with other members of the Latin American clade, including $C$. fimbriata isolates from $T$. cacao that were not pathogenic in inoculation studies $(1,10)$.

Most of the evaluated genetic variation in $C$. cacaofunesta divides the species into two major populations, centered in Ecuador and the Upper Amazon region of Brazil, respectively. Isolates from these two groups are equally pathogenic to cacao (1) but are only partially interfertile (10). These populations differ in several ways, including ITS sequences (1), nuclear and mitochondrial DNA fingerprints, microsatellite markers (11), and karyotype (C. J. Engelbrecht and T. C. Harrington, unpublished data). The popula- 
tions in Ecuador and the Upper Amazon of Brazil have genetic diversity values similar to those expected for indigenous populations of homothallic fungi. Populations collected from Costa Rica, Bahia, and Columbia have genetic diversity values typical of introduced populations and are most similar to the Amazonian population, suggesting that these populations may be a result of introductions of the Amazonian fungus (11). T. cacao is native to the Amazon region, but other species of Theobroma are native to western Ecuador and may be natural hosts of the West Andean population of $C$. cacaofunesta.

Current status of Ceratocystis wilt. As resistant germplasm has been used to effectively manage Ceratocystis wilt, it has been overshadowed by other important cacao diseases. Unfortunately, Ceratocystis wilt is reemerging as an important disease as clonal material is introduced by cacao breeding programs. For example, much propagative material, primarily in the form of cuttings, has been brought to Bahia in recent years in a search for witches' broom resistance. It is possible that $C$. cacaofunesta was introduced to Bahia from the Upper Amazon in such germplasm (6, 11). The pathogen's ability to be carried efficiently in cuttings highlights a need for caution when propagative material is moved throughout the world.

Because much of the germplasm that has been selected for resistance to witches' broom and other diseases has proven to be susceptible to Ceratocystis wilt, the importance of Ceratocystis wilt may also increase as these materials are deployed to combat other diseases. As infested germplasm moves the pathogen to new locations, losses like those that occurred after its introduction to Bahia may become increasingly common. To avoid such losses, all cacao cuttings from regions with Ceratocystis wilt should be grafted and grown under strict quarantine in a greenhouse before field release to ensure that they are free from C. cacaofunesta.

\section{LITERATURE CITED}

1. Baker, C. J., Harrington, T. C., Krauss, U., and Alfenas A. C. 2003. Genetic variability and host specialization in the Latin American clade of Ceratocystis fimbriata. Phytopathology 93:1274-1284.

2. Baker, R. E. D., Cope, F. W., Holliday, P. C., Bartley, B. G., and Taylor, J. 1953. The Anglo-Colombian cacao collecting expedition. In: Reprint Archives Cocoa Research. Vol. 1. H. Toxopeus, ed. Am. Cocoa Res. Inst., Vienna, VA.

3. Barnes, I., Gaur, A., Burgess, T., Roux, J., Wingfield, B. D., and Wingfield, M. J. 2001. Microsatellite markers reflect intra-specific relationships between isolates of the vascular wilt pathogen Ceratocystis fimbriata. Mol. Plant Pathol. 2:319-325.

4. Bastos, C. N. and Evans, H. C. 1978. Ocorrência de Ceratocystis fimbriata Ell \& Halst. na Amazônia Brasileira. Acta Amazonica 8:543-544.

5. Bergmann, J. F. 1969. The distribution of cacao cultivation in pre-Columbian America. Ann. Assoc. Am. Geogr. 59:85-96.

6. Bezerra, J. L. 1997. Ceratocystis fimbriata causing death of budded cocoa seedlings in Bahia, Brazil. Incoped Newsl. 1:6.

7. Cheesman, E. E. 1944. Notes on nomenclature, classification, and possible relationships of cacao populations. Trop. Agric. 21:144-159.

8. Crone, L. J. 1963. Symptoms, spread, and control of canker stain of plane trees. Diss. Abstr. 23:1857-1858.

9. Cuatrecasas, J. 1964. Cacao and its allies. A taxonomic revision on the genus Theobroma. Contrib. Natl. Herb. (USA) 35:379-614.

10. Engelbrecht, C. J. B., and Harrington, T. C. 2005. Intersterility, morphology, and taxonomy of Ceratocystis fimbriata on sweet potato, cacao, and sycamore. Mycologia 97:57-69.

11. Engelbrecht, C. J. B., Harrington, T. C., Alfenas, A. C., and Suarez, C. 2007. Genetic variation of populations of the cacao wilt pathogen, Ceratocystis cacaofunesta. Plant Pathol. (In press.)
12. Figueira, A., Janick, J., Levy, M., and Goldsbrough, P. 1994. Reexamining the classification of Theobroma cacao L. using molecular markers. J. Am. Soc. Hortic. Sci. 119:1073-1082.

13. Harrington, T. C. 2000. Host specialization and speciation in the American wilt pathogen Ceratocystis fimbriata. Fitopatol. Bras. 25:262-263.

14. Hinds, T. E. 1972. Insect transmission of Ceratocystis species associated with aspen cankers. Phytopathology 62:221-225.

15. Iton, E. F. 1960. Studies on a wilt disease of cacao at River Estate. II Some aspects of wind transmission. Pages 47-58 in: Annual Report on Cacao Research, 1959-1960. Imperial College of Tropical Agriculture, St. Augustine, Trinidad.

16. Iton, E. F., and Conway, G. R. 1961. Studies on a wilt disease of cacao at River Estate III. Some aspects of the biology and habits of Xyleborus spp. and their relation to disease transmission. Pages 59-65 in: Annual Report on Cacao Research, 1959-1960. Imperial College of Tropical Agriculture. St. Augustine, Trinidad.

17. Johnson, J. A., Harrington, T. C., and Engelbrecht, C. J. B. 2005. Phylogeny and taxonomy of the North American clade of Ceratocystis fimbriata. Mycologia 97:1067-1092.

18. Laurent, V., Risterucci, A. M., and Lanaud, C. 1993. Variability for nuclear ribosomal genes within Theobroma cacao. Heredity 71:96-103.

19. Laurent, V., Risterucci, A. M., and Lanaud, C. 1994. Genetic diversity in cocoa revealed by cDNA probes. Theor. Appl. Genet. 88:193-198.

20. Laurent, V., Risterucci, A. M., and Lanaud, C. 1994. RFLP study of genetic diversity of Theobroma cacao. Angew. Bot. 68:36-39.

21. Malaguti, G. 1952. Ceratostomella fimbriata en el cacao de Venezuela. Acta Cient. Venez. 3:94-97.

22. Marin, M., Castro, B., Gaitan, A., Preisig, O., Wingfield, B. D., and Wingfield, M. J. 2003. Relationships of Ceratocystis fimbriata isolates from Colombian coffee-growing regions based on molecular data and pathogenicity. J. Phytopathol. 151:395-405.

23. Moller, W. J., and DeVay, J. E. 1968. Insect transmission of Ceratocystis fimbriata in deciduous fruit orchards. Phytopathology 58:14991508.

24. N'goran, J. A. K., Laurent, V., Risterucci, A. M., and Lanaud, C. 1994. Comparative genetic analysis of Theobroma cacao L. using RFLP and RAPD markers. Heredity 73:589-597.

25. Purseglove, J. W. 1968. Tropical crops, Dicotyledons 2. Wiley, New York.

26. Ronning, C. M., and Schnell, R. J. 1994. Allozyme diversity in a germplasm collection of Theobroma cacao L. J. Hered. 85:291-295.

27. Rorer, J. B. 1918. Enfermedades y plagas del cacao en el Ecuador y metodos modernos apropiados al cultivo del cacao. Report on visit to Ecuador to study witchbroom disease (Marasmius perniciosus) of cacao. Council Paper No. 137 of 1933, Government Printer, Port of Spain.

28. Saunders, J. L. 1965. The Xyleborus-Ceratocystis complex of cacao. Cacao 10:7-13.

29. Schieber, E., and Sosa, O. N. 1960. Cacao canker in Guatemala incited by Ceratocysts fimbriata. Plant Dis. Rep. 44:672.

30. Soberanis, W., Rios, R., Arevalo, E., Zuniga, L., Cabezas, O., and Krauss, U. 1999. Increased frequency of phytosanitary pod removal in cacao (Theobroma cacao) increases yield economically in eastern Peru. Crop Prot. 18:677-685.

31. Spence, J. A., and Moll, E. R. 1958. Preliminary observations on a wilt condition of cocoa. J. Agric. Soc. Trin. 58:349-359.

32. Steimel, J., Engelbrecht, C. J. B., and Harrington, T. C. 2004. Development and characterization of microsatellite markers for the fungus Ceratocystis fimbriata. Mol. Ecol. Notes 4:215-218.

33. Thorold, C. A. 1975. Diseases of cocoa. Oxford University Press, Oxford.

34. Warren, J. M. 1994. Isozyme variation in a number of populations of Theobroma cacao L. obtained through various sampling regimes. Euphytica 72:121-126.

35. Whitkus, R., de la Cruz, M., Mota-Bravo, L., and Gómez-Pompa, A. 1998. Genetic diversity and relationships of cacao (Theobroma cacao L.) in southern Mexico. Theor. Appl. Genet. 96:621-627.

36. Witthuhn, R. C., Harrington, T. C., Wingfield, B. D., Steimel, J., and Wingfield, M. J. 2000. Deletion of the MAT-2 mating type gene during uni-directional mating type switching in Ceratocystis. Curr. Genet. 38:4859 . 